\title{
PENGEMBANGAN ALAT PENGKONDISI SUHU OTOMATIS RUMAH WALET BERBASIS MIKROKONTROLER ARDUINO NANO
}

\author{
Edi Suhardi Rahman ${ }^{1}$, Anjas Mara ${ }^{2}$ \\ ${ }^{1}$ Pendidikan Teknik Elektro, Universitas Negeri Makassar \\ edisuhardi@unm.ac.id \\ ${ }^{2}$ Pendidikan Teknik Elektro, Universitas Negeri Makassar \\ Anjasmara90@gmail.com
}

\begin{abstract}
ABSTRAK
Budidaya burung wallet memiliki prospek dan potensi perdagangan yang baik untuk dikembangkan. Saat ini Indonesia menguasai $80 \%$ pasokan pasar dunia sarang walet rumahan. Hingga saat ini masih terdapat beberapa kendala bagi pembudidaya walet diantaraya kesulitaan dalam merekayasa kondisi suhu dan kelembapan pada rumah budidaya burung walet agar menyerupai kondisi di habitat asli serta pengkondisi masih tergolong manual. Pada kajian ini untuk mengetahui hasil pengembangan alat pengkondisi suhu otomatis rumah budidaya burung walet berbasis mikrokontroler Arduino NANO serta tanggapan pengguna terhadap alat tersebut. Metode penelitian yang digunakan melalui pendekatan Research and Development (R\&D) dengan melibatkan 30 responden. Hasil kajian menunjukkan bahwa alat pengkondisi suhu otomatis rumah walet berbasis mikrometer arduiuno mampu bekerja dengan baik, hal ini dibuktikan dengan standar Error pengukuran suhu satu dan dua secara berturut-turut yaitu suhu sensor $18,36 \%, 0,67 \%, 0,63 \%$ dan suhu sensor $29,26 \%, 0,39 \%, 0,81 \%$. Kelembapan sensor $19,86 \%, 0,99 \%, 1,66 \%$ dan kelembapan sensor $211,85 \%, 1,04 \%, 0,64 \%$. Sedangkan hasil analisa tanggapan pengguna menunjukkan bahwa sebanyak $83 \%$ pengguna mengatakan sangat baik dan $17 \%$ pengguna mengatakan baik.
\end{abstract}

Kata Kunci: Arduino, Suhu, Kelembapan, Walet

\section{DEVELOPMENT OF AUTOMATIC TEMPERATURE CONDITIONING TOOLS FOR SWALLOW HOUSES BASED ON ARDUINO NANO MICROCONTROLLERS}

\begin{abstract}
Wallet bird farming has good trading prospects and potential to be developed. Currently, Indonesia controls $80 \%$ of the world market supply of home-made swallow nests. Until now, there are still several obstacles for swallow cultivators, including the difficulty in engineering the temperature and humidity conditions in the swiftlet cultivation house to resemble the conditions in the original habitat and the conditioning is still classified as manual. In this study, to determine the results of the development of an automatic temperature conditioning device for swiftlet cultivation houses based on the Arduino NANO microcontroller and user responses to the tool. The research method used is through a Research and Development $(R \& D)$ approach involving 30 respondents. The results of the study show that the automatic temperature conditioning device for the swiftlet house based on the Arduino micrometer is able to work well, this is evidenced by the standard errors of temperature measurement one and two, respectively, namely temperature sensor $18.36 \%, 0.67 \%, 0.63 \%$ and temperature sensor $29.26 \%, 0.39 \%, 0.81 \%$. The humidity sensor 1 is $9.86 \%$, 0.99\%, 1.66\% and the humidity sensor 2 is $11.85 \%, 1.04 \%, 0.64 \%$. While the results of the analysis of user responses showed that as many as $83 \%$ of users said it was very good and $17 \%$ of users said it was good.
\end{abstract}

Keyword: Arduino, Temperature, Humidity, Swallow 


\section{PENDAHULUAN}

Burung walet merupakan salah satu spesies unggas yang hidup di alam bebas. Burung walet memiliki sepasang grandula salivales yang terletak di bawah lidah. Bangsa Cina pada masa kekuasaan Dinasti Ming (1368-1644) mempopulerkan sarang burung walet ke seluruh dunia, dimana pada saat itu masakan sarang burung walet sangat terkenal [1].

Menurut [2] pada ada awalnya, burung walet banyak menghuni gua-gua alam yang terdapat di pegunungan atau bukit-bukit di tepi laut. Karakteristik gua yang lembab, bersuhu dingin, dan memiliki pencahayaan yang terbatas memang sangat disukai burung walet. Seiring perjalanannya, banyak gua-gua tempat habitat asli burung walet yang rusak. Akibatnya, burung walet harus mencari tempat baru untuk tempat bersarang dan berkembang biak. Maka tak aneh jika kawanan burung walet akan menempati ruangruang atau bangunan kosong yang memang tidak diperuntukkan bagi tempat walet bersarang.

Melihat dari kondisi permasalahan yang sering di alami oleh para pembudidaya burung walet dipengaruhi oleh berbagai faktor, diantaranya kondisi suhu dan kelembapan pada rumah budidaya burung walet yang susah di buat seperti kondisi di habitat aslinya. Permasalahan lain yang sering di hadapi oleh pembudidaya walet adalah alat pengkondisi suhu yang di pakai oleh para pembudidaya walet umumnya masih manual yang dimana mengharuskan petani walet harus mengecek secara berkala dan tentunya harus masuk ke dalam rumah walet, pengecekan suhu dan kelembapan yang dilakukan di rumah budidaya walet ini akan menggangu keyamanan burung wallet sehingga bisa mengakibatkan populasi didalam rumah walet akan sulit untuk bertambah. Permasalahan yang juga sering di alami pembudidaya burung walet adalah alat pengkondisi suhu dan kelembapan yang dipakai oleh para pembudidaya walet umumnya hanya mampu mengkondisikan pada satu lantai saja sehingga dilantai lain sulit mencapai suhu dan kelembapan yang ideal. Maka dalam penelitian ini dibuat suatu alat pengkondisi suhu otomatis pada rumah budidaya burung walet tradisional berbasis mikrokontroler Ardunino NANO menggunakan sensor DHT 11 yang mampu mengkondisikan lebih dari satu lantai. Sistem pengontrolan dibuat dengan menggunakan mikrokontroler, sensor suhu, selenoid valve dan motor pam, dan Nozzel Sprinkler.

\section{METODE PENELITIAN}

\section{A. Jenis Penelitian}

Penelitian ini menggunakan pendekatan penelitian dan pengembangan atau dikenal Research and Development (R\&D). R\&D adalah metode penelitian yang digunakan untuk menghasilkan produk tertentu, dan menguji keefektifan produk tersebut.

\section{B. Model Pengembangan}

Model pengembangan yang digunakan pada penelitian ini adalah prototype (prototyping). Prototyping adalah proses pembuatan model sederhana dari suatu produk yang mengijinkan pengguna memiliki gambaran dasar tentang produk serta melakukan pengujian awal. Prototyping memberikan fasilitas bagi pengembang dan pengguna untuk saling berinteraksi selama proses pembuatan, sehingga pengembang dapat dengan mudah memodelkan perangkat yang akat dibuat.

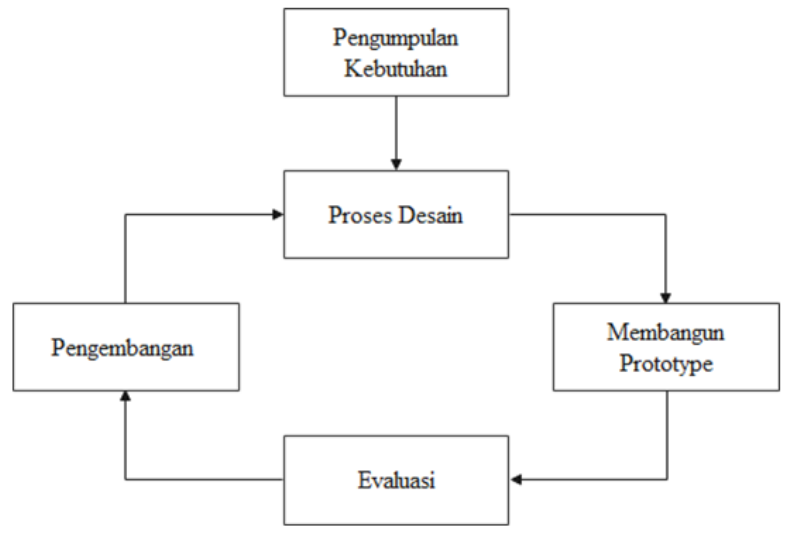

Gambar 1. Model Prototype

\section{Desain Pengembangan}

Alat pengkondisi suhu otomatis rumah walet yang akan didesain dengan beberapa tahapan yaitu:

\section{Perancangan Sistem}

\section{a. Blok Diagram}

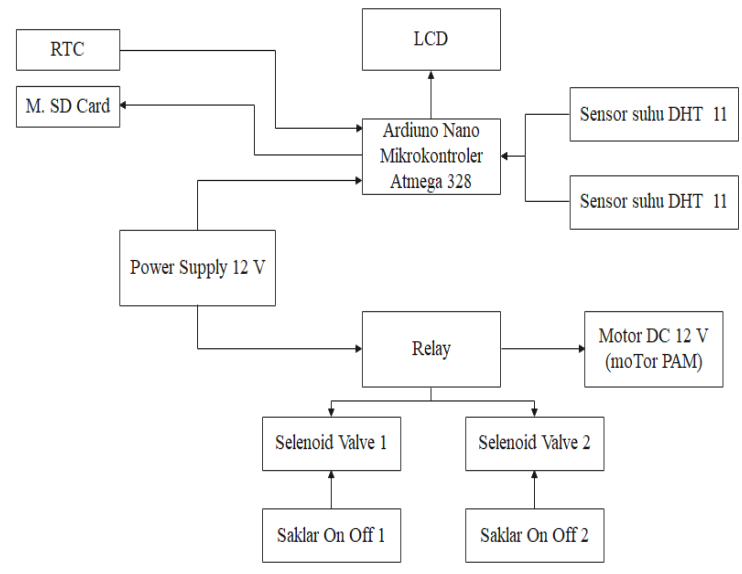

Gambar 2. Blok Diagram Perencanaan 
Blok diagram dibutuhkan untuk mempermudah memahami alur kerja dari sistem penelitian yang akan dirancang, berikut merupakan blok digram alat pengkondisi suhu otomatis rumah walet berbasis mikrokontroler Arduino Nano.

\section{b. Prinsip Kerja}

Berikut adalah gambaran prinsip kerja alat pengkondisi suhu otomatis rumah walet berbasis mikrokontroler Arduino Nano.

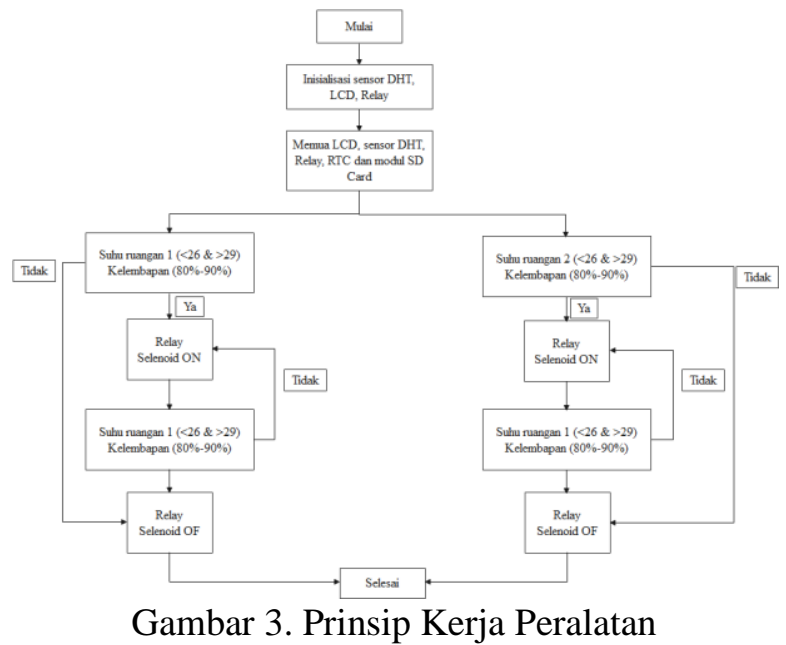

\section{Sistem Kerja Rangkaian}

Cara kerja alat secara keseluruhan dapat digambarkan melalui diagram blok diatas yang mana terdapat beberapa komponen utama untuk menunjang sistem kerja alat pengkondisi suhu otomatis rumah walet ini diantaranya Sensor Suhu DHT 11, Power Supply, Relay, Arduino NANO, Stepdown, Selenoid Valve, , LCD, Modul SD Card, dan RTC.

Power supply itu berfungsi untuk mengirim atau memberikan tegangan kerja pada step down $d c$ dan relay, step down $d c$ berfungsi untuk menurunkan tegangan dari $12 \mathrm{v}$ dc ke $9 \mathrm{v}$ dc, nntinya tegangan output $9 \mathrm{v}$ dc ini akan menyalakan mikrokontroller Arduino Nano.

Sensor DHT 11 akan membaca suhu dan kelembapan ruangan yang data pembacaan pembacaan suhunya akan dikirimkan ke Arduino NANO untuk diproses data yang dihasilkan oleh Sensor DHT 11. Hasil data yang sudah diproses oleh Arduino NANO menggunakan Mikrokontroller Atmega 328 akan akan menentukan kapan relay akan bekerja. Modul SD Card akan menyimpan hasil data pembacaan sensor DHT 11 sedangkan RTC akan mencatat Waktu dan tanggal hasil Pembacaan yang kemudian akan di simpan di memori.
Arduino NANO yang telah di program untuk menyalakan relay yang terhubung ke selenoid alve dengan suhu $28^{\circ}$, maka pada saat Sensor DHT 11 membaca suhu ruangan tepat pada suhu $28^{\circ}$ maka relay akan menyalakan selenoid valve, begitupun sebaliknya ketika sensor DHT 11 membaca suhu ruangan tepat pada suhu $26^{\circ}$ maka akan mematikan selenoid valve. Kemudian pembacaan Sensor DHT 11 data hasil pantauan akan dikirimkan ke layar monitor LCD.

\section{Prosedur Penelitian}

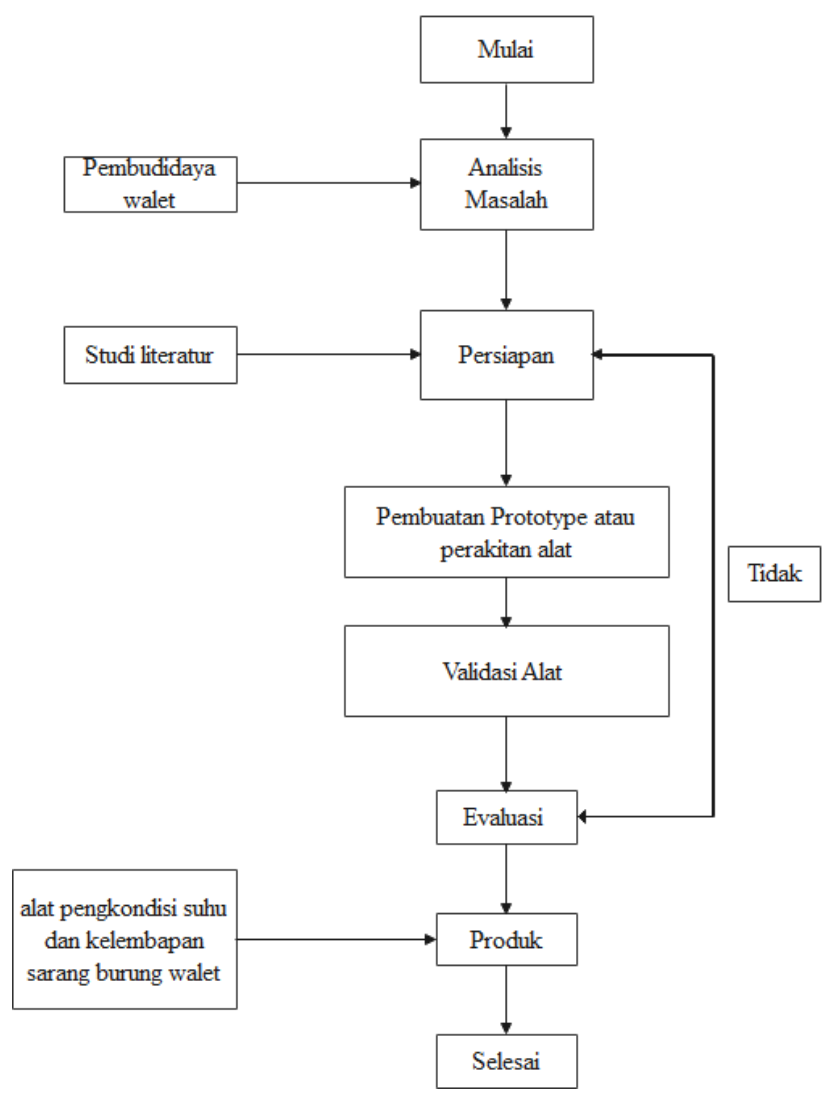

Gambar 4. Tahapan Penelitian

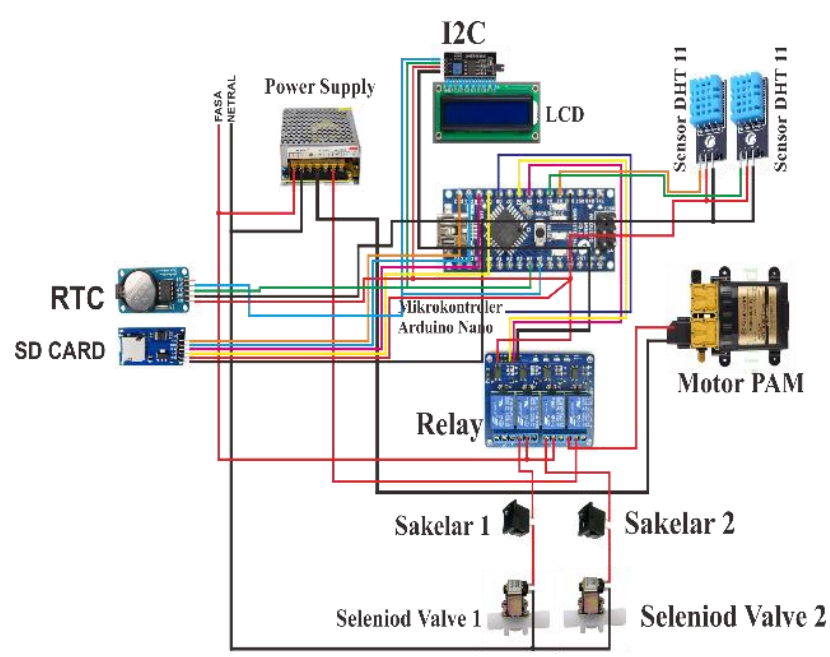

Gambar 5. Perakitan Perangkat 


\section{E. Teknik Analisis Data}

\section{Analisis Funcionality}

Pengujian Functionality ditentukan dari hasil perhitungan skor persentase untuk masing-masing instrumen. Pada lembar jawaban setiap item pertanyaan menggunakan skala guttman. Skala pengukuran dengan tipe ini akan didapat jawaban yang tegas yaitu ya/tidak, benar/salah, pernah/tidah pernah, positif/negatif [3]. Jawaban dapat dibuat dalam bentuk checklist dengan skor tinggi satu dan skor rendah nol.

\section{Pengujian Usability}

Analisis kualitas untuk karakteristik usability dilakukan dengan menganalisis respon pengguna. Respon pengguna dilihat berdasarkan kuesioner yang menggunakan skala likert dengan 5 alternatif jawaban dan memiliki tingkatan skor yang berbeda [4].

Hasil persentase di atas kemudian dibandingkan dengan skala likert, yaitu skala yang digunakan untuk mengukur sikap, pendapat, dan persepsi seseorang atau sekelompok orang tentang suatu kejadian [5]. Pengelompokan tingkat persentase sesuai skala likert dapat dilihat pada Tabel berikut:

\begin{tabular}{ll}
\multicolumn{2}{c}{ TABEL 1. KONVERSI KUALITATIF DARI } \\
PERSENTASE KELAYAKAN \\
\hline Persentase Kelayakan & Kriteria \\
\hline $81 \%-100 \%$ & Sangat Baik \\
$61 \%-80 \%$ & Baik \\
$41 \%-60 \%$ & Cukup \\
$21 \%-40 \%$ & Kurang \\
$<20 \%$ & Sangat Kurang \\
\hline
\end{tabular}

\section{HASIL DAN PEMBAHASAN}

\section{A. Hasil Penelitian}

\section{Deskripsi Produk}

Penelitian ini dilakukan untuk mengembangkan sebuah alat pengkondisi suhu dan kelembapan rumah budidaya walet yang sudah otomatis menggunakan Arduino Nano. Alat ini bertujuan untuk memudahkan pembudidaya walet mengkondisikan suhu dan kelembapan rumah budidaya waletnya. Alat ini menggunakan Sensor DHT 11 untuk membaca Suhu dan kelembapan, dimana Sensor DHT 11 ini akan mengirim hasil pembacaan ke Arduino Nano yang kemudian arduino nano akan mengontrol relay berdasarkan suhu dan kelembapan yang telah diprogram. Relay ini kemudian berfungsi untuk mengaktifkan selenoid valve jika suhu tidak sesuai yang diprogram dan akan menonaktifkan selenoid valve jika suhu sudah sesuai yang diprogram. Suhu yang diinginkan adalah $26-29^{\circ}$ dan kelembapan yang diinginkan adalah $80-90 \%$. Alat ini juga bisa dikontrol secara manual dengan menggunakan saklar, saklar ini berfungsi mengontrol selenoid valvel jika kita hanya ingin mengkondisikan suhu dan kelembapan pada ruangan yang diinginkan.

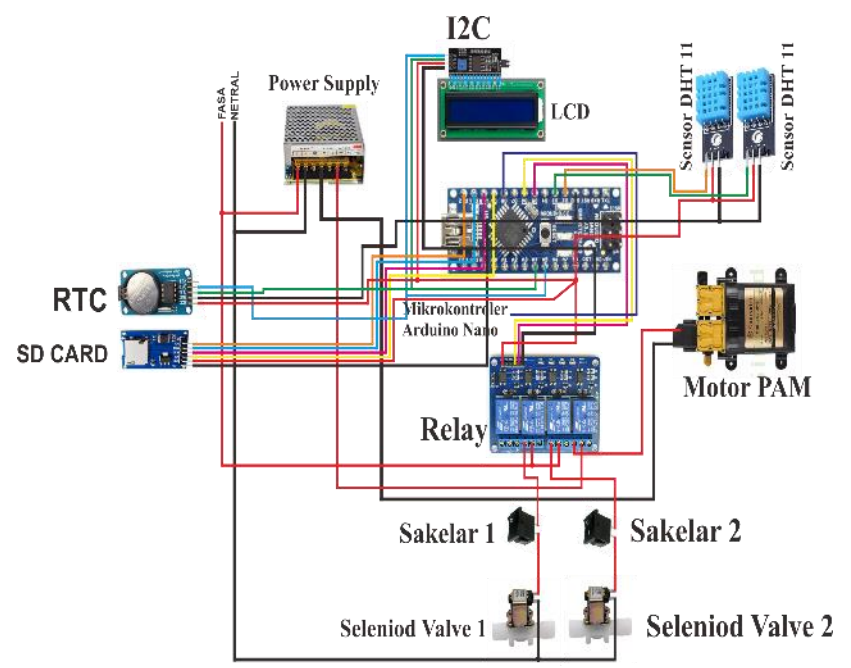

Gambar 6. Rangkaian Alat Pengembangan

\section{Hasil Pengujian}

a. Pengujian Rangkaian

1) Pengujian Mikrokontroler Arduino Nano

Pengujian mikrokontroller arduino nano dilakukan dengan cara melakukan pengecekan pada pin-pin arduino nano dengan tujuan untuk mengetahui apakah pin-pin arduino berfungsi dengan baik, pinpin arduino digunakan sebagai input/output untuk menjalankan sistem.

\section{TABEL 2. PIN ARDUINO}

\begin{tabular}{cccc}
\hline No & Pin Arduino & Nilai & Kondisi \\
\hline 1 & Pin D0 & 1 & Berfungsi dengan baik \\
2 & Pin D1 & 1 & Berfungsi dengan baik \\
3 & Pin D2 & 1 & Berfungsi dengan baik \\
4 & Pin D3 & 1 & Berfungsi dengan baik \\
5 & Pin D4 & 1 & Berfungsi dengan baik \\
6 & Pin D5 & 1 & Berfungsi dengan baik \\
7 & Pin D6 & 1 & Berfungsi dengan baik \\
8 & Pin D7 & 1 & Berfungsi dengan baik \\
9 & Pin D8 & 1 & Berfungsi dengan baik \\
10 & Pin D9 & 1 & Berfungsi dengan baik \\
11 & Pin D10 & 1 & Berfungsi dengan baik \\
12 & Pin D11 & 1 & Berfungsi dengan baik \\
13 & Pin D12 & 1 & Berfungsi dengan baik \\
14 & Pin D13 & 1 & Berfungsi dengan baik \\
10 & GND & 1 & Berfungsi dengan baik \\
11 & VREF & 1 & Berfungsi dengan baik \\
12 & 3 V3 & 1 & Berfungsi dengan baik \\
13 & A0 & 1 & Berfungsi dengan baik \\
14 & A1 & 1 & Berfungsi dengan baik
\end{tabular}




\begin{tabular}{cccc}
\hline No & Pin Arduino & Nilai & Kondisi \\
\hline 15 & A2 & 1 & Berfungsi dengan baik \\
16 & A3 & 1 & Berfungsi dengan baik \\
17 & A4 & 1 & Berfungsi dengan baik \\
18 & A5 & 1 & Berfungsi dengan baik \\
19 & A6 & 1 & Berfungsi dengan baik \\
20 & A7 & 1 & Berfungsi dengan baik \\
18 & Vin & 1 & Berfungsi dengan baik \\
19 & $5 \mathrm{v}$ & 1 & Berfungsi dengan baik \\
20 & Reset & 1 & Berfungsi dengan baik \\
\hline
\end{tabular}

TABEL 3. PENGUJIAN SENSOR SUHU DHT 11

\begin{tabular}{llllll}
\hline NO & $\begin{array}{l}\text { Pengukuran } \\
\text { Yang Ke }\end{array}$ & $\begin{array}{l}\text { Suhu } \\
\text { Alat } \\
\left({ }^{\circ} \mathbf{C}\right)\end{array}$ & $\begin{array}{l}\text { Termometer } \\
\left({ }^{\circ} \mathbf{C}\right)\end{array}$ & Selisih & Error \\
\hline 1 & 1 & 28,3 & 29 & 0.7 & $2,41 \%$ \\
2 & 2 & 28,2 & 28,9 & 0,7 & $2,42 \%$ \\
3 & 3 & 28,9 & 29,7 & 0,8 & $2,69 \%$ \\
4 & 4 & 28,3 & 29,6 & 1,3 & $4,39 \%$ \\
5 & 5 & 28,7 & 29,9 & 1,2 & $4,01 \%$ \\
\hline \multicolumn{7}{c}{ Rata - Rata Error $(\mathbf{\%})$} \\
\hline \multicolumn{7}{c}{ TABEL 4. PENGUJIAN KELEMBAPAN SENSO DHT 11 } \\
\hline No & Pengukuran & Kelembapan & Termometer & Selisih & Eror \\
\multicolumn{7}{c}{ Alat } & & & $(\%)$ \\
\hline 1 & 1 & 80,75 & 81 & 0,25 & 0,30 \\
2 & 2 & 80,75 & 82 & 1,25 & 1,52 \\
3 & 3 & 80,75 & 82 & 1,25 & 1,52 \\
4 & 4 & 80,75 & 81 & 0,25 & 0,30 \\
5 & 5 & 80,75 & 0,25 & 0,30 \\
\hline \multicolumn{7}{c}{ Rata-Rata Error (\%) } \\
\hline
\end{tabular}

2) Pengujian LCD $20 \times 4$

Pada pengujian LCD 20x4 dilakukan untuk menampilkan tegangan, arus, daya dan energi listrik yang mengalir pada suatu rangkaian dengan menggunakan beberapa beban untuk mengetahui nilai pembacaan sensor, untuk melakukan pengujian pada komponen ini peneliti mengupload listing program berikut.

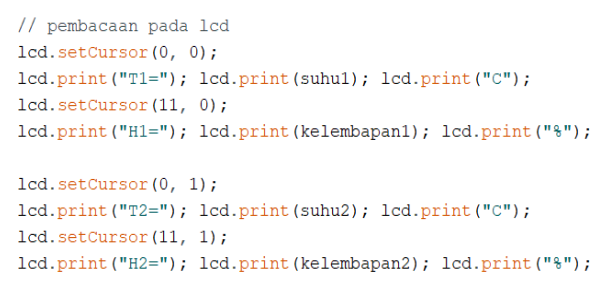

\section{Gambar 7. Listing Program LCD}

\section{3) Pengujian Power Supply}

Pada pengujian Power Supply dilakukan untuk mengetahui apakah Power Supply dapat memberikan tegangan sebesar 12 volt DC yang kemudian akan digunakan untuk menyalakan Arduino Nano. Hasil pengujian Power Supply ditampilkan pada gambar di bawah ini.

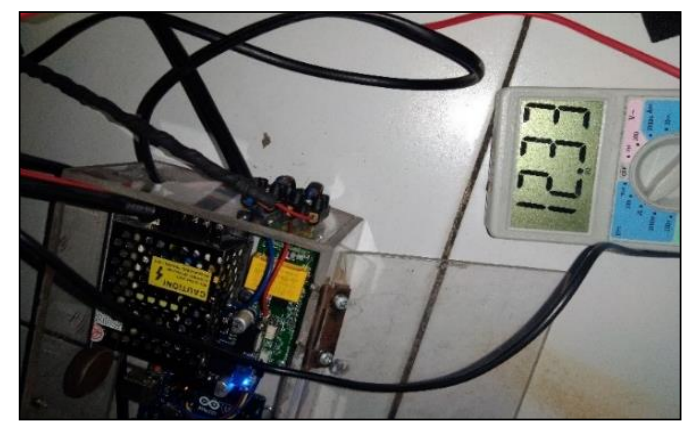

Gambar 8. Hasil Pengujian Power Supply

4) Pengujian Sensor DHT 11

Pengujian sensor DHT11 ini bertujuan untuk mengetahui kemampuan sensor dalam menerima rangsangan perubahan suhu pada ruang terbuka. Pengujian dilakukan dengan membandingkan suhu dari termometer dengan data suhu DHT11.

5) Pengujian Relay

Pengujian ini bertujuan untuk mengetahui apakah relay berfungsi dengan baik atau tidak, ketika suhu di atas $29^{\circ}$ dan kelembapan di bawah $80 \%$ maka relay akan menyala dan mengaktifkan selenoid dan ketika suhu dan kelembapan sudah sesuai yang diinginkan maka relay akan menonaktifkan selenoid.

\section{6) Pengujian Selenoid Valve}

Pengujian ini bertujuan untuk mengetahui apakah Selenoid Valve berfungsi dengan baik atau tidak, ketika selenoid aktif maka akan membuka penutup jalur air yang ada didalam selenoid dan ketika selenoid non aktif maka akan menutup jalur air yang ada di selenoid, berikut hasil pengujian selenoid valve.

7) Pengujian Motor PAM

Pengujian ini bertujuan untuk mengetahui apakah Selenoid Valve berfungsi dengan baik atau tidak, dimana ketika relay yang menghubungkan motor aktif maka motor akan menyala, dan ketika relay yang menghubungkan motor non aktif maka motor akan mati.

8) Pengujian Sakelar

Pengujian ini bertujuan untuk apakah sakelar ini berfungsi dengan baik atau tidak, dimana ketika sakelar pada kondisi of maka selenoid valve tidak akan bekerja dan ketika sakelar pada kondisi on maka seleoid valve akan bekerja.

9) Pengujian Modul SD Card

Pengujian ini bertujuan untuk apakah Modul $S D$ Card ini berfungsi dengan baik, dimana Modul $S d$ Card ini akan menyimpan data hasil pembacaan dari Sensor DHT 11.

10) Pengujian RTC

Pengujian ini bertujuan untuk mengetahui apakah RTC ini Berfungsi dengan baik, dimana RTC ini Meyimpan data waktu dan tanggal data hasil pembacaan dari Sensor DHT 11 yang kemudian akan di simpan di SD Card. 
11) Pengujian Secara Keseluruhan

Pengujian ini bertujuan untuk mengetahui kinerja sistem secara keseluruhan, dimana pengujian ini dilakukan dengan cara membandingkan tingkat akurasi pengukuran rancangan dengan alat ukur standar. Hasil pengujian ditampilkan sebagai berikut. Pengujian kinerja sistem secara keseluruhan dilakukan selama 3 hari pengamatan. Pengamatan berkala dilakukan tiap 1 jam, hal ini untuk mendapatkan data yang lebih akurat dan spesifik.

b. Pengujian Instrumen

1) Kualitas Functionality

Pengujian karakteristik funcionality menggunakan metode black box testing dimana penguji akan menilai berdasarkan instrumen test case. Instrumen pengujian functionality berisi 16 pertanyaan yang menjabarkan subkarakteristik suitability dan accurancy.

Dari kedua validator menyatakan bahwa setiap test-case yang dilakukan mendapatkan hasil yang sesuai dengan fungsinya. Analisis dari pengujian functionality menggunakan metode analisis deskriptif diperoleh persentase kelayakan seperti pada Table berikut :

TABEL 5. PERSENTASE KELAYAKAN PENGUJIAN FUNCIONALITY

\begin{tabular}{cc}
\hline Item Pertanyaan & Persentase Kelayakan \\
\hline 1. & $100 \%$ \\
2. & $100 \%$ \\
3. & $100 \%$ \\
4. & $100 \%$ \\
5. & $100 \%$ \\
6. & $100 \%$ \\
7. & $100 \%$ \\
8. & $100 \%$ \\
9. & $100 \%$ \\
10. & $100 \%$ \\
11. & $100 \%$ \\
12. & $100 \%$ \\
13. & $100 \%$ \\
14. & $100 \%$ \\
15. & $100 \%$ \\
16. & $100 \%$ \\
\hline
\end{tabular}

Berdasarkan hasil analisis deskriptif di atas lalu dikonversikan pada tabel konversi nilai dan didapat hasil persentase kelayakan Alat dari sisi karakteristik functionality bernilai $100 \%$ dan memiliki interpretasi Sangat Baik.
2) Usability

Usability merupakan faktor penting dalam pengembangan suatu alat diciptakan untuk memenuhi kebutuhan pengguna, sehingga kemudahan pengguna dalam menggunakan alat lebih diutamakan. Untuk pengujian usability, menggunakan kuesioner yang dikembangkan [6].

3) Kajian Komponen Produk

a) Perangkat Keras (Hardware)

Perangkat keras (Hardware) yang ada pada alat ini menggunakan beberapa komponen yang terdiri dari input dan output. Perangkat input terdiri dari sensor DHT 11, yang dihubungkan ke Arduino Nano, adapun perangkat pengendali pada sistem ini adalah Arduino Nano, sedangkan perangkat output pada sistem ini adalah LCD, RTC, Modul SD Card dan Relay. Dalam proses kerjanya, mikrokontroller Arduino Nano dijalankan dengan bantuan program menggunakan software teks editor dan compiler yang disebut dengan Arduino IDE (Integrated Development Environtment). Program tersebut mempunyai peranan penting sebagai penggerak sistem kerja alat secara keseluruhan.

Perangkat lunak (Software) yang digunakan peneliti untuk mengendalikan pengembangan sistem kontrol monitoring dan pembatas energi listrik ini menggunakan aplikasi desktop "Arduino" yang menggunakan bahasa $\mathrm{C}$ (berekstensi *.c) yang selanjutnya dirubah kedalam bahasa yang dimengerti oleh microcontroller (file berekstensi *.hex) dengan software IDE (Integrated Development Environment).

b) Perangkat Lunak (Software)

Perangkat lunak (Software) yang digunakan peneliti untuk mengendalikan pengembangan sistem kontrol monitoring dan pembatas energi listrik ini menggunakan aplikasi desktop "Arduino" yang menggunakan bahasa $\mathrm{C}$ (berekstensi *.c) yang selanjutnya dirubah kedalam bahasa yang dimengerti oleh microcontroller (file berekstensi *.hex) dengan software IDE (Integrated Development Environment).

\section{B. Pembahasan}

Alat pengkondisi suhu otomatis rumah walet merupakan sebuah alat yang dikembangkan untuk kebutuhan pembudidaya walet agar bisa memudahkan mengkondisikan atau mengatur suhu dan kelembapan secara otomatis pada rumah walet. Alat pengkondisi suhu yang di pakai oleh para pembudidaya walet umumnya masih manual yang dimana mengharuskan petani walet harus mengecek secara berkala dan tentunya mengharuskan petani walet masuk ke rumah walet. Aktifiktas pengecekan berkala alat pengkondisi suhu ini akan mengganggu kenyamanan walet sehingga bisa mengakibatkan populasi didalam rumah walet akan sulit untuk bertambah dikarenakan walet 
bisa saja mengalami stres. Melihat dari penjelasan diatas maka dibutuhkanlah alat untuk mengontrol secara otomatis alat pengkondisi suhu pada rumah walet tersebut.

Cara penggunaan dari alat pengkondisi suhu otomatis rumah walet ini dimana peneliti menyalakan power supply DC 12 Volt dimana tegangan keluaran 12 Volt DC dari power supply ini digunakan untuk menyalakan Arduino Nano.

Pemanfaatan arduino dalam pembuatan alat ini untuk memproses data yang diberikan oleh Sensor DHT 11 sebagai sensor untuk membaca suhu dan kelembapan didalam rumah walet, kemudian hasil pembacaan sensor dikirimkan ke LCD untuk ditampilkan. RTC akan mengirim data waktu dan tanggal pembacaan data dari sensor DHT 11 yang kemudian akan di simpan oleh Sd card, Modul SD Card ini akan menyimpan hasil pembacaan suhu dan kelembapan. Ketika suhu dan kelembapan belum mencapai kondisi ideal dimana kondisi ideal suhu $26^{\circ}-29^{\circ}$ dan kelembapan $80 \%$ - 90\% maka akan membuat relay akan aktif dan membuka kerang sirkuit yang ada pada selenoid valve, relay ini juga akan menyalakan pompa yang kemudian akan memompa air yang dialirkan menggunakan selang $6 \mathrm{~mm}$ yang dimana output selang ini ada nozzel yang akan menyemprotkan air menjadi butiran air. Sedangkan ketika suhu dan kelembapan sudah mencapai kondisi ideal dimana kondisi ideal suhu $26^{\circ}-29^{\circ}$ dan kelembapan $80 \%$ - 90\% maka akan membuat relay akan aktif dan membuka kerang sirkuit yang ada pada selenoid alve, relay ini juga akan mematikan pompa yang dimana pompa akan berhenti mengalirkan air ke selang. Selain alat ini juga bisa berfungsi otomatis alat ini juga bisa di kontrol manual dengan menggunakan saklar yang ada di box kontroling yang mana saklar 1 berguna untuk menonaktifkan selenoid valve 1 dan saklar 2 berguna untuk menonaktifkan selenoid valve 2 .

Berdasarkan pengembangan alat pengkondisi suhu otomatis rumah walet menggunakan mikrokontroler yang telah dilakukan pengujian. Dalam hal ini pengujian dilakukan dengan membandingkan hasil pengukuran alat rancangan dengan alat ukur standar untuk mendapatkan hasil persentase kesalahan (error) pada alat rancangan. Setelah dihitung secara keseluruhan dan diratarata maka nilai simpangan atau persentase kesalahan hitung alat ukur rancangan terhadap alat ukur standar, nilai \% error alat ukur sensor suhu 1 dan 2 dengan termometer selama 3, hari ke-1 nilai error sensor suhu 1 sebesar $8,13 \%$ dan sensor suhu $29,22 \%$, pada hari ke-2 nilai error sensor suhu 1 sebesar $0,67 \%$ dan sensor suhu $20,39 \%$, pada hari ke-3 nilai error sensor suhu 1 sebesar $0,56 \%$ dan sensor suhu 2 0,23\%, sedangkan untuk nilai \% error alat ukur sensor kelembapan 1 dan 2 dengan termometer selama 3, hari ke-1 nilai error sensor kelembapan 1 sebesar 10,55 \% dan sensor kelembapan 2 10,6 \%, pada hari ke-2 nilai error sensor kelembapan 1 sebesar $0,96 \%$ dan sensor kelembapan $21,01 \%$, pada hari ke-3 nilai error sensor kelembapan 1 sebesar 0,86\% dan sensor kelembapan $20,91 \%$.

Selain pengujian alat dan aplikasi terdapat uji funcionality dan usability, dimana funcionality diujikan ke validator didapat hasil persentase kelayakan alat dari sisi karakteristik functionality bernilai $100 \%$ dan memiliki interpretasi sangat baik. Sedangkan dalam uji usability diperoleh kesimpulan bahwa 25 orang responden mengatakan sangat baik atau $83 \%$ dan 5 orang responden mengatakan baik atau $17 \%$ dari jumlah responden, sedangkan untuk kategori cukup, kurang, sangat kurang sebanyak 0 orang atau $0 \%$.

\section{SIMPULAN}

Pengembangan alat pengkondisi suhu otomatis rumah walet berbasis mikrokontroler arduino nano untuk mengatur dan memantau suhu dan kelembapan yang ada didalam rumah budidaya walet, sensor DHT 11 berfungsi untuk membaca suhu dan kelembapan. suhu dan kelembapan rumah budidaya walet yang ideal dimana suhu $26^{\circ}-29^{\circ} \mathrm{C}$ dan kelembapan ideal $80-90 \%$. Hasil pengukuran standar error suhu 1 dan 2 secara berturut turut yaitu Suhu sensor $18,13 \%$, $0,67 \%, 0,56 \%$ dan suhu sensor $29,22 \%, 0,39 \%$, $0,23 \%$. Kelembapan sensor $110,55 \%, 0,96 \%, 0,86 \%$ dan kelembapan sensor $210,6 \%, 1,01 \%, 0,91 \%$.

Pengujian alat dan aplikasi terdapat uji funcionality dan usability, dimana funcionality diujikan ke validator didapat hasil persentase kelayakan alat dari sisi karakteristik functionality bernilai $100 \%$ dan memiliki interpretasi sangat baik. Sedangkan dalam uji usability diperoleh kesimpulan bahwa 25 orang responden mengatakan sangat baik atau $83 \%$ dan 5 orang responden mengatakan baik atau $17 \%$ dari jumlah responden, sedangkan untuk kategori cukup, kurang, sangat kurang sebanyak 0 orang atau $0 \%$.

\section{DAFTAR PUSTAKA}

[1] H. K. Nugroho, A. Budiman, and P. S. Tim Penulis, "Panduan Lengkap Walet," Depok: Penebar Swadaya, 2009.

[2] N. Salekat, Membangun Rumah Walet Hemat Biaya. Agromedia Pustaka, 2009.

[3] Sugiyono, Metode Penelitian Pendidikan (Pendekatan Kuantitatif, Kualitatif dan R\&D). 
Bandung: Alfabeta, 2017.

[4] Rudiwan, Skala Pengukuran Variabelvariabel Penelitian. Bandung: Alfabeta, 2013.

[5] U. Guritno, S., Sudaryono, \& Rahardja, Theory And Application Of IT Research: Metodologi Penelitian Teknologi Informasi. Yogyakarta: Andi, 2011.

[6] A. Yulianty and A. Kurniawati, "Quality Analysis of Bios Portal Website at Banking Companies Using ISO/IEC 25010: 2011 Method". 